\title{
La educación pública: escenario de conflictos y acuerdos entre católicos y liberales en la Argentina de fines del siglo XIX y comienzos del $X X$
}

\author{
Lucía Lionetti
}

IEHS-Universidad del Centro de la Provincia de Buenos Aires, Tandil

En la Argentina de fines del siglo XIX, la intelligentsia liberal consideró a la escuela pública como el instrumento más adecuado para formar al ciudadano. En esas circunstancias los "católicos" y "liberales" libraron uno de los debates más citados por la historiografía argentina. En el presente trabajo se vuelve sobre ese debate para los límites de la confrontación de valores entre el modelo de educación confesional y el de escuela pública laica sobre el que se pretendía construir la estabilidad de la república.

PAlabRas ClaVE: Educación, debate, liberales, católicos, ciudadanía.

In Argentina, at the end of the 19th century, liberal intelligentsia considered the state public school as the best means to educate the citizens. The subject put face to face "liberal" and "catholic" leaders. This conflict was one of the most mentioned in Argentine historiography. The aim of this article is to analyse the political and ideological dimensions of that contest and the limits of the confrontation of values between both educational models: the secular public school and the confessional education.

KEYWORDS: Education, debate, liberals, catholics, citizenship.

En la Argentina, los primeros signos de lo que los contemporáneos llamaron el "progreso" se percibieron desde mediados del siglo XIX, cuando el mundo comenzó la integración plena del mercado y la gran expansión del capitalismo; sin embargo, sus alcances fueron limitados. Faltaba emprender la principal de las tareas: la consolidación del Estado. Para 1880 estaban delineadas, en sus rasgos básicos, las instituciones del Estado: el sistema fiscal, el judicial, el administrativo. No obstante, debían ser desarrollados, era necesario implementar las estrategias - cooptación, coer- 
ción y penetración — ${ }^{1}$ para conseguir la homogenización estatal. Se contaron, en un principio, con escasos medios e instrumentos para realizar las tareas más urgentes, como educar o fomentar la inmigración. Hasta que la disponibilidad de recursos fue suficiente, ese Estado asoció y fomentó la acción de los particulares y de las propias provincias. Recién cuando contó con sus propias instituciones consiguió avanzar y adelantarse a la iniciativa de la sociedad civil.

La notable expansión de la agricultura y la ganadería marcó el rumbo del "progreso argentino". ${ }^{2}$ El motor de ese crecimiento económico fue, sin duda, la exportación de productos primarios (cuero, lana, cereales y carne). Argentina participó activamente en ese marco de internacionalización económica donde el trabajo, el capital y la producción primaria y secundaria eran materia de intercambio, en ese mundo en movimiento, la inmigración cubrió las necesidades de mano de obra que exigía la expansión. En la década de 1880, los recién llegados se concentraron en las grandes ciudades, en la construcción de sus obras públicas y la remodelación urbana. A mediados de la década siguiente, ante el aumento de la demanda de trabajo, algunos inmigrantes se instalaron en la zona rural, a quienes se sumaban luego los que viajaban anualmente para trabajar en las cosechas. Entre 1880 y 1890 los arribados superaron el millón, y los efectivamente radicados fueron unos 650.000, una cantidad notable para un país que contaba con dos millones de pobladores aproximadamente. En la década siguiente, luego de la crisis de 1890, se redujo la llegada y los que retornaban a su tierra de origen fueron, de año en año, más que los que arribaban. El ritmo se restableció en la primera década del siglo XX, cuando los saldos positivos superaron el millón.

En esa Argentina en expansión, los hombres de la elite se habían reservado el manejo de la alta política, en tanto era considerada una actividad de "notables". Las prácticas electorales de la época y la fuerte injerencia del gobierno desalentaban a los que quisieran participar de la batalla por la alternancia en el poder ya que la red clientelar, tutelada por las autoridades, garantizaba la seguridad del triunfo en cada contienda electoral.

1 Los análisis de esas distintas estrategias fueron trabajados por Oszlak, O.: La formación del Estado Argentino, Editorial Belgrano, Buenos Aires, 1982.

2 Cortés Conde, Roberto: El Progreso Argentino 1880-1914, Sudamericana, Buenos Aires, 1978. Pucciarelli, Alfredo: El capitalismo agrario pampeano, Hyspamérica, Buenos Aires, 1986. Un enfoque más actual sobre esta expansión económica se puede encontrar en la sección "Perspectivas sobre la historia de la industrialización argentina (1880-1930), Anuario IEHS, 13, Tandil, 1998. 
Indudablemente, los rasgos de ese sistema político llevaban a una escasa participación de los ciudadanos en los actos electorales. Sin embargo, era también necesario ampliar las bases consensuales: de este modo, conseguir el ejercicio de una ciudadanía activa se convirtió entonces, en un desafío para la elite dirigente. ${ }^{3}$

El régimen se sustentó en un concepto relativamente amplio de "ciudadano", que incluía a todos los varones adultos nativos o nacionalizados (los extranjeros votaban exclusivamente en el ámbito municipal), y que lo acercaba más al citoyen de la Francia revolucionaria que al ciudadano propietario propuesto por Locke. Como explica Sábato, esas prácticas electorales cumplieron un papel central en la construcción de una esfera política que se relacionaba de manera compleja con la esfera social, pero que no podía reducirse a ella. En el marco de esa red política, los votantes no eran ciudadanos individuales, libres y autónomos. Los pocos que votaban lo hacían enrolados en fuerzas electorales que participaban en las tumultuosas jornadas de comicios. ${ }^{4}$

La falta de competencia entre partidos permitió la estructuración de un partido único, cuyo jefe era el Presidente de la República. El Partido Autonomista Nacional era efectivamente una federación de gobernadores, notables de las provincias, y el presidente usaba sus atribuciones institucionales para disciplinarla. En síntesis, una instancia de acuerdos donde se confundía aquello que era propio del Estado con lo llanamente político. ${ }^{5} \mathrm{En}$ esa línea, el gobierno de Julio Argentino Roca, prestigioso general que culminó la llamada "Conquista del Desierto" y miembro de la elite cordobesa, inauguró el régimen del ochenta que promovió la mutación social y económica en una difícil convivencia con aquel ejercicio restringido de la política.

Fue ese régimen liberal-conservador el que emprendió la tarea modernizadora de la sociedad, ganando espacios para convertir al Estado en protagonista de esa transformación. La Ley de Registro Civil y de Matrimonio

3 Véase Sabato, Hilda: La política en las calles. Entre el voto y la movilización. Buenos Aires 1862-1880, Sudamericana, Buenos Aires, 1998.

4 Véase Sabato, Hilda: "Introducción" en Sabato, Hilda (coord..): Ciudadanía política y formación de las naciones. Perspectiva histórica de América Latina, El Colegio de México, México, 1999, pág. 25

5 Para un análisis clásico sobre este régimen político véase Botana, Natalio: El Orden Conservador.. También se puede consultar, Gallo, Ezequiel: Los nombres del poder, FCE, Buenos Aires, 1997. Gallo, Ezequiel: "Política y sociedad en la Argentina, 1870-1916", en Bethell, Lesli (comp.), Historia de América Latina, vol. X, Crítica, Barcelona, 1992. 


\section{LUCÍA LIONETTI}

Civil (1882), la Ley 1420 de educación común, gratuita y obligatoria (1884) fueron la muestra clara de la intención de avanzar sobre instituciones como la Iglesia y las asociaciones de las colectividades extranjeras. La creación de un sistema monetario (1898), la ley de conscripción militar obligatoria (1902) y la reforma electoral (1912), fueron otras instancias claves de esa política que llevó a la consolidación del estado nacional y a la implementación del proyecto modernizador.

Como sostiene Ricardo Salvatore, la mirada que la historiografía argentina hizo de ese proceso subrayó alternativamente los recursos fiscales y administrativos que hicieron posible la existencia de un estado nacional, los mecanismos que generaron un sistema de hegemonía política oligárquica, la base jurídica de la soberanía y el ejercicio del poder y la construcción de un proyecto nacional. Al parecer hubo poco interés por explicar los aspectos culturales y disciplinarios de la construcción del Estado, por lo tanto, la transformación del poder estatal como complejo cultural e institucional —sus estructuras de gobierno, sus razones para gobernar, sus prácticas - quedó relativamente inexplorada. Una omisión que resulta notable, para un país y un período que se consideraron paradigmáticos de los procesos de rápida modernización económica y sociocultural. ${ }^{6}$

A partir de esa sugerencia se vuelve a estudiar el modelo de educación pública de los hombres de la Argentina moderna, considerado una de las principales vías para concretar la modernización. Los cambios que se producían en pleno contexto de construcción del Estado nacional y de definición de una nación para el desierto argentino $^{7}$ se consolidaban si eran acompañados con la educación del pueblo. El progreso material era una de las caras de la civilización, pero su triunfo definitivo se alcanzaría cuando se consiguiera imponer en la sociedad la moralidad en las costumbres, la fidelidad a la patria, el respeto a las instituciones de la república, la dedicación al trabajo y la fortaleza de espíritu. Los hombres de la generación del ochenta esperaron que, por medio de la escuela pública, se consiguiera hacer efectivo ese modelo de ciudadanía.

La escuela pública fue considerada como el instrumento más adecuado para formar al ciudadano. La socialización política proyectada a partir

6 Salvatore, Ricardo: "Sobre el surgimiento del estado médico legal en la Argentina (18901940)" en Estudios sociales 20 (1. ${ }^{\circ}$ semestre 2001), págs. 82-83.

7 Halperin Donghi,Tulio: "Una nación para el desierto argentino", en Proyecto y construcción de una nación, Biblioteca Ayacucho, Caracas, 1980. 
de una escuela abierta para todos los niños de la república, varones y mujeres, ricos y pobres, nativos e inmigrantes preveía la conformación de una ciudadanía entendida en un sentido amplio, superador de la estricta cuestión del derecho a elegir y ser elegido. Inspirados en las modernas políticas de los Estados nacionales, más que plantearse el problema de la representación política, les interesó configurar una sociedad civil sobre la que se edificaría el orden y la estabilidad de la república. ${ }^{8}$

A pesar de ese acuerdo, el campo educativo generó debates, controversias y negociaciones, que expresaron un cruce de ideas formuladas por aquellos actores interesados en esta cuestión, encuentros y desencuentros, batallas verbales que se libraron a lo largo de estos años y que implicaron una toma de posición política e ideológica por parte de los involucrados. Fue precisamente en las instancias de implementación del proyecto destinado a "educar al soberano" con su impulso secularizador, que se instaló uno de los debates más citados por la historiografía nacional. En una primera aproximación, ante la opinión pública, dos posturas quedaron claramente definidas: la de aquellos que defendieron la enseñanza de la religión como medio para conseguir moralizar las costumbres del pueblo y la de quienes asumieron el compromiso de garantizar una educación libre e igualitaria para todos los habitantes de la nación, es decir, un discurso claramente dirigido a los hombres y mujeres provenientes de otras latitudes que profesaban cultos diferentes.

Esas dos tesis, que disputaron la preponderancia en la definición de ese proyecto educativo, alcanzaron su punto de mayor inflexión a comienzos de los ochenta. Fue en el ámbito del Congreso donde "católicos" y "liberales" libraron su batalla más conocida, que culminó con la sanción de la Ley de educación común. En el presente trabajo se retoma este debate para analizar, en una segunda instancia, hasta qué punto los contenidos de la enseñanza, proyectados para ser dictados en la escuela pública, eran incompatibles con el modelo de enseñanza religiosa tal como argumentaron unos y otros en el recinto legislativo. En definitiva, se intenta develar la dimensión de esa batalla político-ideológica y determinar si efectivamente

8 En ese sentido, más allá de algunos cuestionamientos realizados a su planteo, resultan útiles las dimensiones analíticas que planteara T.H.Marshall en su tradicional trabajo de los años cincuenta, Class, Citizenship, and Social Development. Algunas de las críticas que se formularon a su trabajo han sido presentadas en Turner, Bryan S: "Outline of a Theory of Citizenship" en Sociology, vol.24, mayo 1990, págs.189-217 y Roche, Maurice: "Citizenship Social Theory and Social Change", Theory and Society, 16, 1987, págs. 363-399. 


\section{LUCÍA LIONETTI}

se puede plantear una ruptura entre el universo de valores difundido en las escuelas privadas confesionales y la escuela pública laica, inspirada en las modernas teorías pedagógicas.

\section{Voces y protagonistas del debate por el tipo de educación}

La controversia por el tipo de formación que se debía brindar en la educación de los niños y niñas se había generado antes de la década del ochenta y continuó luego de que se sancionara la Ley 1420. Ya desde mediados del siglo XIX habían aparecido las primeras voces a favor de una educación de carácter laico en las escuelas públicas. Una de las más destacadas fue la de Juana Manso, notable y emprendedora educacionista del Río de la Plata. Después de la caída del régimen de Juan Manuel de Rosas, en 1852, regresó de su exilio a Buenos Aires para trabajar junto a Domingo Faustino Sarmiento, considerado el máximo precursor de la educación en la Argentina. En 1858 se convirtió en editora de Álbum de Señoritas, ${ }^{9}$ donde, desde su lugar de mujer "ilustrada", criticó tanto la enseñanza religiosa tradicional como la que recibían los varones y las niñas. Al tomar la palabra, se pronunció a favor de una educación que permitiera liberar a las mujeres. Cuando señaló que "[...] quería probar que la inteligencia de la mujer, lejos de ser un absurdo, un defecto, un desatino o un crimen, es su mejor 'adorno', su verdadera fuente de virtud [...]", ${ }^{10}$ se granjeó la condena de la opinión influyente de su época.

Extinguida esta publicación, Manso comenzó a colaborar en los Anales de Educación Común, primer órgano pedagógico de la Argentina,

9 Sobre las ideas que transmitió en ese periódico se puede consultar: Masiello, Francine (comp.): La mujer y el espacio público, Feminaria Editora, Buenos Aires, 1994. Fletcher, Lea (comp.): Mujeres y cultura en la Argentina del siglo XIX, Buenos Aires, 1967. Auza, Néstor: Periodismo y feminismo en la Argentina: 1830-1930, Emecé, Buenos Aires, 1968.

10 Album de Señoritas, nº, pág.1. Una de las batallas verbales más conocidas fue la que mantuvo con la influyente Mariquita Sánchez que, en su momento, se había destacado como uno de los personajes más activos de la sociedad porteña en los días de la independencia de las colonias del Virreinato del Río de la Plata. Esta mujer de la elite porteña en su carácter de presidenta de la Sociedad de Beneficencia de Buenos Aires defendió un tipo de enseñanza para las "señoritas" que chocaba con las modernas corrientes pedagógicas que defendía Manso y que sostenía la coeducación de los sexos y el carácter laico de la enseñanza. Esta cuestión ha sido trabajada en Lionetti, Lucía: "La educación, un campo de acción, para la conquista de la ciudadanía de la mujer en Argentina a lo largo del siglo XIX" en Pérez Canto, Pilar y Bandieri, Susana (comp.): Educación, género y ciudadanía en Argentina, siglos XIX y XX, Editorial Miño y Dávila, Buenos Aires, (en prensa). 
fundado el 1 de noviembre en 1858. Poco después, cuando Sarmiento asumió como Director General de Escuelas en 1860 con la intención de reimplantar la coeducación de niños y niñas en las escuelas de Buenos Aires, Manso fue designada Directora de la Escuela Primaria $\mathrm{N}^{\circ} 1$ para ambos sexos. La dirigió durante seis años pero, con el cambio de las autoridades escolares y al ordenarse nuevamente la separación de varones y niñas, sintió la necesidad de alejarse. En 1871 fue designada como vicedirectora interina de la Escuela Graduada $\mathrm{N}^{\circ} 1 \mathrm{y}$, al año siguiente, Nicolás Avellaneda, ministro de instrucción pública en la presidencia de Sarmiento, la nombró miembro de la Comisión Nacional de Escuelas. Desde el ejercicio de su cargo, Sarmiento reconoció públicamente las condiciones de educadora de su amiga confiándole la traducción de la obra de Horacio Mann y Norman Calkins, Lecciones sobre objetos para los maestros y los padres. Al año siguiente, la educadora fundó en el mismo año la Sociedad Pestalozzi, originalmente conocida con el nombre de Sociedad de Educación y el periódico Educación Moderna. Sin embargo, los obstáculos y permanentes cuestionamientos a su obra como miembro del Departamento de Escuelas siempre estuvieron presentes al extremo de dejar fuera de circulación por cinco meses la revista los Anales. La batalla personal librada por esta "mujer republicana liberal" 11 contra los personajes influyentes de su tiempo se mantuvo a lo largo de estos años. Cuando murió en 1875, comenzaban a darse los primeros pasos efectivos que convirtieron a la educación en una cuestión de Estado. ${ }^{12}$

El aforismo alberdiano "gobernar es poblar" devino en un nuevo mandato: "gobernar es educar". Era necesario garantizar el derecho a una educación común mediante la sanción de un "plan de instrucción general del que hablaba la Constitución". ${ }^{13}$ En esta línea, el ministro de Culto, Justicia e Instrucción Pública, Onésimo Leguizamón, al resumir los principios pilares en que debía sustentarse el proyecto educativo moderniza-

11 Véase Femenias, María Luisa: "Tres escenas del feminismo Argentino" en Femenias, María Luisa (Comp.), Perfiles del feminismo iberoamericano, Editorial Catálogos, Buenos Aires, 2002.

12 Una de las medidas concretas que tomó el gobierno nacional en estos años fue la creación de la Escuela Normal de Paraná (Provincia de Entre Ríos) en 1870 con el propósito de capacitar al "ejército de profesionales", "apóstoles de la educación", para la "misión" de educar. En esta institución, modelo de formación bajo las modernas corrientes pedagógicas, se formaron los maestros/as y pedagogos más reconocidos de fines del XIX y principios del XX.

13 Memoria de Instrucción Pública, Imprenta Americana, Buenos Aires 1875, pág. XLII. 
dor, introdujo un aspecto que desencadenaría el conflicto, al señalar que "si bien todo hombre debe tener una religión, y que cada uno quiera enseñarla a sus hijos, la escuela pública, costeada con la renta de los hombres de diversas religiones, no puede servir para enseñar a una exclusivamente sino con el consentimiento de los padres". ${ }^{14}$

De este modo, el consenso en torno a la presencia del Estado en materia de instrucción mostró su primer quiebro cuando hubo que precisar el tipo de formación que se dictaría en las aulas. La controversia entre los dirigentes liberales y los católicos se agudizó sobre todo a partir de 1880. La prensa fue el canal del que se valieron ambos bandos para llegar a la opinión pública en defensa de la causa y la denotación del rival. Sarmiento fue una de las figuras descollantes de esa polémica asumiendo, desde las páginas de El Nacional, la firme defensa de la educación laica; enfrentado a sus compañeros del Consejo Nacional de Educación, al ministro Pizarro, al ex-presidente Nicolás Avellaneda, escribió los comentarios más irónicos y agudos en la saga de artículos que publicó bajo el título "La escuela sin la religión de mi mujer". ${ }^{15}$ Por su parte, Mitre desde La Nación, Paul Groussac, Lucio V. López, Carlos Pellegrini, Roque Sáenz Peña, Delfín Gallo y otros, en Sud América, José C. Paz como director de La Prensa y sus editorialistas fueron las figuras más notorias que se sumaron a la defensa de la escuela laica. A favor de la enseñanza religiosa, en La Unión, José Manuel Estrada, Pedro Goyena, Emilio Lamarca, Tristán Achával Rodríguez y Miguel Navarro Viola fueron las voces más relevantes del pensamiento católico en aquel debate.

Para evitar tensiones se convino que en el primer Congreso Pedagógico de Buenos Aires convocado en 1882, ${ }^{16}$ donde participaron invitados del resto de Hispanoamérica y de España, no se tratara el tema de la enseñanza religiosa. De este modo, el debate se trasladó al ámbito del Congreso

14 Idem.

15 El Nacional, 1883. A lo largo de ese año en sus comentarios, aludía a la extraordinaria presión que ejercerían sobre las autoridades nacionales las damas católicas, especialmente "la esposa del doctor Avellaneda que lo impulsa a defender la enseñanza religiosa en nuestras escuelas argentinas". Ibídem, 12 febrero de 1883. Para los liberales de la época, aquellas mujeres que asumían la defensa de la religión católica eran la expresión de un obstáculo a la modernidad. Al respecto se puede consultar Mead, Karen: "Gendering the Obstacles to Progress in Positivist Argentina, 1880-1920", HAHR, vol. 77, 4, noviembre De 1997, págs. 645-675.

16 Esta cuestión se ha trabajado en Cucuzza, Héctor: De Congreso a Congreso. Crónica del Primer Congreso Pedagógico, Besana, Buenos Aires, 1986. 
Nacional ${ }^{17}$ cuando se discutieron el proyecto de la Comisión de Instrucción Pública y Culto presentado por la bancada de diputados católicos, en el que se establecía la enseñanza religiosa obligatoria, y el proyecto de educación común de los diputados liberales, en sustitución del de la Comisión, en el que se defendía la enseñanza laica. La propuesta de los legisladores liberales se inspiró en la ley belga de 1879 que excluía la religión de la enseñanza oficial, limitándose a permitir que los ministros de las diversas comuniones, antes o después de las horas de clase, asistiesen a la escuela para dar la enseñanza de su doctrina respectiva. Se dejaba expresa constancia que "la enseñanza religiosa sólo podrá ser dada en las escuelas públicas por los ministros autorizados de los distintos cultos, a los niños de su respectiva comunión, y antes o después de las horas de clase". ${ }^{18}$

Se puede decir que, en aquellas circunstancias, la postura de los "católicos" quedó debilitada ante el avance de la política estatal y su voluntad de abrir "la escuela pública para todos los niños del país" sin carácter confesional. Sin embargo, el núcleo de legisladores católicos argumentó a favor de la enseñanza de la religión y moral —exonerando a los padres de familia que no profesaban el catolicismo de la obligación de enviar a sus hijos para ser instruidos en esa religión - declarando como necesidad primordial "la de formar el carácter de los hombres por la enseñanza de la religión católica y las instituciones republicanas". ${ }^{19}$

En la Cámara el debate comenzó con la presentación del diputado católico Achával Rodríguez, que cuestionó el proyecto de la bancada liberal por desconocer el artículo $5 .^{\circ}$ de la Constitución Nacional que delegaba la instrucción primaria a los gobiernos provinciales. Esta ley, según argumentó, afectaría además a las escuelas privadas que dieran una instrucción contraria a la dispuesta por las autoridades nacionales. Ante la pregunta de a quién corresponde enseñar, sostenía:

“[...] que los elementos del hogar, que los elementos del pueblo, la escuela particular, que los elementos religiosos, como poder indispensable en un Estado, y que el esta-

17 Ese debate también se reveló de modo interesante en las diversas peticiones que católicos y liberales presentaron en su momento en el recinto del poder legislativo. Se puede decir que fue un debate detrás del debate planteado entre los legisladores y que merece un tratamiento aparte. Un llamativo trabajo al respecto es el de Cuccorese, Horacio Juan: "Historia de las ideas, la 'cuestión religiosa' en 1883 a través del derecho de petición presentado en el Congreso Argentino. Las manifestaciones populares", Academia Nacional de la Historia, t. IV, Buenos Aires, 1967.

18 Idem.

19 Citado por Campobasi, José Salvador: Ataque y defensa de la ley nacional 1420, Ediciones Trabajo, Rosario, 1968, pág. 53. 


\section{LUCÍA LIONETTI}

do mismo, tiene en cada uno de ellos el derecho y el deber de tomar al individuo apenas sale del seno de la madre, para hacerlo hombre, es decir, para hacerlo religioso, moral, cívico; para desenvolver en él, en una palabra, todas sus facultades naturales, y ponerlo así en condiciones de cumplir su misión [...]

Se pretende, señor Presidente, que es el Estado quien debe dirigir única y exclusivamente la enseñanza, quien debe preparar la inteligencia del individuo, y que sin esa intromisión del Estado no puede existir la escuela particular. Y a este respecto se considera que hay un defecto en el proyecto de la Comisión". ${ }^{20}$

Con este proyecto de ley, tal como lo entendía, se atacaba una de las más preciosas garantías establecidas en la Constitución, "el derecho de ¡enseñar y aprender libremente!". ${ }^{21}$ Por eso se debía salvar la escuela "libre", puesto que era la única garantía posible de la libertad en la vida práctica. La otra objeción que presentó fue la proscripción de la enseñanza religiosa en la escuela oficial; desde su perspectiva, era una afirmación terrible el considerar inconciliable la enseñanza religiosa con las instituciones democráticas, no podía existir una sociedad bien organizada sin religión, allí estaba el ejemplo de los Estados Unidos y su escuela oficial:

“¿Cómo entran los niños en la escuela oficial en los Estados Unidos? Allí se abren todas las aulas oficiales, todas las escuelas particulares con este primer acto obligado: recitando los niños la oración dominical, el padre nuestro en que todas las sectas y comuniones están conformes. Practican, pues, los niños, la religión desde que pisan los umbrales de la escuela. [...] Esta es la escuela de los Estados Unidos. No es la escuela indiferente: es la escuela religiosa. [...] El pueblo de los Estados Unidos se encuentra dividido por innumerables sectas, que surgen del protestantismo, y entonces el Estado ha comprendido que no era posible tomar un credo común, sin herir a unas sectas favoreciendo a otras"22.

Se proclamó por esa razón, como un "liberal” en la verdadera acepción de la palabra, de modo que no existían dentro del parlamento argentino esas divisiones de tipo político como se quería suponer. Lo que marcaba la diferencia era la convicción de que el maestro no podía enseñar moral si se prohibía toda noción de religión en la escuela. ${ }^{23}$ En su opinión, esa

20 Transcrito en Pesce Batailana, Carlos: Los Diputados Católicos ante la Ley 1420, Librería Santa Catalina, Buenos Aires, 1933. págs.148-149.

21 Ibídem, pág. 150.

22 Ibídem, pág. 157-158.

23 Para defender ese argumento con perspicacia dijo: "El niño preguntaría: ¿Por qué no he de matar? ¿Qué le contestaría el maestro? Porque el niño le observaría: 'mato al buey; el hombre se muere: es un hecho natural que sucede todos los días ¿Por qué no mataría yo al hombre que me estorba?' ¿Qué contestación le daría el maestro? No hay más que una; le diría: no puedes matar al hombre porque tiene otra vida, que no tiene el buey que matamos para alimentarnos; porque nuestra misión no está 
enseñanza no debía reducirse exclusivamente al hogar, ya que no se podía confundir la educación con la instrucción propiamente dicha. ${ }^{24}$

En el debate, desde la posición católica participó también quien fuera reconocido como un brillante político, Pedro Goyena. En su alegato recordó que la propia Constitución exigía como requisito para ser Presidente de la República pertenecer a la confesión católica. Por tanto, en sus funciones debía estar animado del espíritu del catolicismo, tener respeto por él, en atención a las funciones de patrono, como un hijo de la Iglesia, nunca con propósitos de hostilidad y animadversión hacia ella. Aclaró que el tipo de liberalismo que criticaba era el que promovía la "idolatría del Estado", aquel que concebía "la vida social, la administración, el gobierno, completamente desvinculados de la religión”. ${ }^{25}$ Allí residía el mayor atentado contra la libertad:

"Cuando el Estado es concebido como una entidad superior a los derechos individuales, que no respeta el deber y la facultad del padre de familia como educador de sus hijos, -que no respeta a la Iglesia en su misión docente, que no respeta el principio religioso, -¿qué es lo que sucede? El Estado lo llena todo, mata toda iniciativa; y orgulloso de su predominio, con el deseo de conservarlo, legisla de esta manera". ${ }^{26}$

Según su argumento, ese liberalismo se asemejaba a la aplicación del materialismo, del ateísmo a la vida civil, que eliminaba la iniciativa particular. Ése era el cariz que había tomado la civilización moderna, dominada por los intereses materiales a expensas del desarrollo de las virtudes del hombre. La ciencia, a la que la Iglesia no había sido nunca hostil, tomaba ese rumbo extraviado por la influencia de ese orgullo insensato. Por eso las sociedades contemporáneas no hacían más que ofrecer "un desnivel chocante entre su grandeza material y la exigüidad, la pobreza, la debilidad de sus elementos morales". ${ }^{27}$

Goyena no tenía dudas, "la escuela debe ser religiosa [...]. Se enseñará, pues, la religión nacional, se enseñará la religión que sostiene la Constitución de la República" ${ }^{28}$ La realidad del país indicaba que

concluida (sic) aquí, en esta vida, continúa en otra. [...] El maestro tendrá que enseñar al niño que hay un principio supremo que viene de lo Alto que se llama principio de autoridad; y que no es cuestión simplemente de conveniencia; sino que tiene en virtud de ese principio el deber de respetar y cumplir las leyes de su país”. Ibídem, pág. 164-165.

24 Véase Ibídem, pág. 165.

25 Ibídem, pág. 206.

26 Ibídem.

27 Ibídem, pág. 209.

28 Ibídem, págs. 215-218. 


\title{
LUCÍA LIONETTI
}

\begin{abstract}
"Siendo nuestro clero tan reducido, relativamente a la población, será imposible que los sacerdotes den la enseñanza religiosa a un gran número de niños, llenando al mismo tiempo los otros deberes de su ministerio, sobre todo si se tiene en cuenta que esos niños no están preparados por el conocimiento del Catecismo, adquirido en la escuela. [...]

A este respecto puedo invocar la opinión de Guizot, quien decía en un debate análogo al presente: la enseñanza moral, la enseñanza religiosa, si ha de ser eficaz, no puede circunscribirse a tiempo y lugar determinados; no se moralizan a tan bajo precio y en condiciones tan fáciles, las generaciones que forman un pueblo. No; aquella enseñanza debe ser de todos los momentos y de todos los lugares: debe ser como una atmósfera que envuelva siempre al niño; sólo así ejerce sobre el alma y sobre la vida, toda su saludable acción". ${ }^{29}$
\end{abstract}

El cruce de argumentos llegó a un punto clave. Los diputados católicos no rebatían el proyecto de enseñanza oficial, lo que cuestionaban era la ausencia de la enseñanza religiosa. Achával Rodríguez proclamaba en defensa de la enseñanza de la religión la necesidad de anteponer la formación del hombre antes que la del ciudadano. Ésta había sido la gran conquista de los principios modernos: el "sagrado" principio de los derechos individuales. Ante las palabras del ministro de Instrucción Pública, Eduardo Wilde, "el Estado hace ciudadanos, la Iglesia hace católicos". Su respuesta fue: "el Estado hace el ciudadano; la iglesia hace el hombre". ${ }^{30}$ Aquel mandato convertía a la Iglesia en un poder social, una institución gobernante con jurisdicción temporal y una inevitable relación con el Estado:

"Si el Estado no puede prescindir de tener religión, es decir no puede prescindir de adoptar verdades religiosas, como fundamento de su legislación; si no puede, por consiguiente, dejar de adoptar las verdades que tienen por objeto y enseña esta institución que se llama Iglesia; el Estado no puede tampoco desconocer a la Iglesia, a la institución social docente, la parte que le corresponde en el gobierno de la sociedad y, por lo mismo, la jurisdicción requerida por ese gobierno. [...] el Estado no puede ser separado de la Iglesia de una manera absoluta; mucho menos si la Iglesia es una institución a la cual pertenece la totalidad de los habitantes del Estado: desde que la Iglesia es la depositaria del credo de todos ellos, el Estado no puede estar completamente separado de la Iglesia". ${ }^{31}$

En función de esa relación, el Estado debía acompañar la enseñanza religiosa que comenzaba primeramente en el hogar, donde se brindaba la

29 Ibídem, págs. 220-221.

30 Ibídem, pág. 270.

31 Ibídem, págs. 276-277. 
educación del ejemplo dirigida al corazón, pero su alcance era limitado en tanto que,

\begin{abstract}
"El artesano, el jornalero, que tiene que abandonar la casa y salir desde la mañana a buscar el pan cotidiano para el alimento de sus hijos, no puede dedicarse a desenvolver la inteligencia de sus hijos. La madre pobre, que ocupada en los quehaceres de la familia, tiene todo su tiempo absorbido por estas necesarias ocupaciones de preparar el alimento de sus hijos, de asear sus ropas, etc., no puede tampoco dedicarse a cultivar las facultades intelectuales de éstos con la extensión indispensable.

Toda la enseñanza que pueda recibir allí el niño, será la enseñanza del ejemplo que le ofrezca la conducta moral de sus padres.

¿Qué es, qué debe ser la enseñanza primaria, en tal caso?

La escuela primaria es y debe ser el complemento del hogar. En ella deben existir todos los elementos necesarios para continuar y complementar la obra del hogar, es decir, para poner en ejercicio y cultivar todas las facultades del niño. En ellas debe haber los elementos necesarios para cultivar las facultades morales, el corazón, los sentimientos, y para desenvolver, a la vez, las facultades intelectuales y de la voluntad.

El señor Ministro decía con mucha razón: la escuela debe ser integral”. ${ }^{32}$
\end{abstract}

En la escuela primaria, casi un hogar, el maestro debía dictar al niño nociones respecto del hombre, pero sus enseñanzas debían contener aspectos que demostraran su creencia religiosa. Si no tenía religión o si procedía como si no lo tuviera y se apartaba completamente de toda verdad religiosa, daría una enseñanza atea. La enseñanza de religión impartida por un sacerdote o por el cura párroco fuera de horas de clase, después de una lección de historia, física o cualquier otra materia dada por un maestro sin religión, era un peligro para la educación del niño. Si bien era importante que existiera una asignatura especial de religión, lo más importante era que "el maestro ha de ser religioso". ${ }^{33}$ Por lo tanto, la escuela debía dotarse de maestros católicos. Ante la pregunta del diputado Calvo, si aquello implicaba excluir a los maestros de las demás religiones, volvía a recordar que su propuesta era que se subvencionara las escuelas privadas.

Si la inmensa mayoría del pueblo argentino profesaba la comunión católica, apostólica y romana, se preguntaba el legislador católico, por qué no introducir su enseñanza en la legislación sobre la educación primaria. Desde su perspectiva, el proyecto revelaba el "contagio de las doctrinas que nos llegan en el soplo revolucionario de la Francia", ${ }^{44}$ para recordar los cos-

32 Ibídem, pág. 303.

33 Ibídem, pág. 307.

34 Ibídem, pág. 328. 


\section{LUCÍA LIONETTI}

tosos riesgos corridos cuando Gambetta convirtió la cuestión política en cuestión social, haciendo imposible la República. Por eso, ante la defensa del diputado Gallo del proyecto oficial, Achával Rodríguez volvía sobre su afirmación. "[...] el maestro no debe ser solamente religioso en la enseñanza religiosa. La enseñanza de la geología, la enseñanza de la filosofía, etc., deben estar basadas sobre las grandes verdades de la revelación" ${ }^{35}$ El legislador avanzaba sobre una cuestión de fondo: el origen del conocimiento. El fundamento del conocimiento era la religión y no la ciencia.

Ante el argumento de Gallo sobre el carácter neutro de la escuela de los Estados Unidos, donde sólo se rezaba en la apertura de la clase una oración, la respuesta del diputado católico fue la misma: "Mientras tanto nosotros sostenemos que la enseñanza toda debe ser religiosa". ${ }^{36}$ En su alegato final, reiteraba ejemplos como el de Bélgica donde supuestamente la exclusión de la religión llevaba a una indiferencia que provocaría el derrumbe social.

Para impugnar el despacho de la Comisión de Instrucción y Culto, pedir su rechazo y su reemplazo por un proyecto de ley presentado por sus colegas - y que resultara posteriormente la base fundamental de la Ley 1420 — habló el diputado liberal Onésimo Leguizamón. ${ }^{37}$ Explicó que si la educación era un medio de gobierno, no debía dársele un sentido contrario a las instituciones del país, ya que el poder de cada nación era el responsable de los destinos del pueblo llamado a educarse. Por lo tanto,

“[...] La educación debe ser completamente obligatoria, necesariamente obligatoria, hasta sus últimas consecuencias. Si no fuese obligatoria, el deber de la educación existiría al lado del derecho de la ignorancia, y esto es más que una contradicción palmaria, es un absurdo. [...] Su consecuencia natural es el otro principio, la educación debe ser gratuita, porque la educación obligatoria supone, como condición y explica-

35 Ibídem, pág. 329.

36 Ibídem, pág. 331.

37 Cabe señalar que en oportunidad de desempeñarse como ministro de Culto, Justicia e Instrucción Pública y Culto, se había anticipado sobre esta cuestión sosteniendo: "[...] es el momento de dictar el plan de instrucción general del que hablaba la Constitución para conseguir ese impulso homogéneo a través de una ley común, una ley superior en la que se contemple la educación laica [...] sólo para los pueblos católicos el asunto tiene novedad. La Inglaterra misma tan subordinada a la influencia de la iglesia anglicana en materia de educación, rompió hace cinco años con el pasado para decretar la más radical secularización de las escuelas. No por eso han demolido sus históricos establecimientos de Eton y Arrow, donde los hijos de la nobleza de Inglaterra recibían una educación clásica y viril según la expresión de Montalambert, bajo la dirección de algunos miembros eminentes del clero anglicano. Nada de eso. El pueblo inglés reforma conservando, jamás demoliendo [...]". Ver, Memoria de Culto, Justicia e Instrucción Pública, Imprenta Americana, Buenos Aires, 1875, pág. XLIII. 
ción, la existencia de la escuela gratuita al alcance de los niños a quienes obliga a ser educados. [...] La educación tiene que ser en consecuencia necesariamente gradual, con arreglo de los preceptos de la naturaleza. [...] La educación debe tener un objeto esencial: desarrollar simultáneamente la inteligencia, la parte moral del niño, y también su capacidad y sus medios físicos. La educación debe ser dada, en consecuencia, con arreglo a los principios de la higiene, necesaria, obligatoriamente con arreglo a los principios del desarrollo físico. [...]." ${ }^{38}$

Leguizamón cuestionó que el proyecto de la comisión no contuviera una palabra sobre la educación de la mujer y se refirió especialmente a las aptitudes de la condición femenina para el ejercicio del magisterio. ${ }^{39} \mathrm{Al}$ mismo tiempo, consideraba que se exigían ciertas condiciones para el maestro oficial y nada se exponía sobre el maestro privado. Así se aseguraría la enseñanza de la verdad en la escuela pública y dejaría en libertad para que se enseñara la mentira en la escuela privada. En lo relativo a la profesión del maestro, consideró que la ley era muy deficiente puesto que exigía ciertas condiciones de capacidad, pero no determinaba qué condiciones, y no hacía referencia a la estabilidad del magisterio, dado que ese factor era de sustancial importancia para garantizar su propio desarrollo, su moralidad y su ilustración.

En otro aspecto, se explayó sobre el carácter que debía tener la inspección a la que presentó de dos maneras, técnica y administrativa. La primera correspondía a los maestros, hombres competentes; la administrativa, referida a la higiene, a la moral y a la disciplina de las escuelas, tenía que estar entregada, con arreglo de las nociones sociales comunes en materia de educación, a los padres de familia; es decir, al vecindario, al distrito escolar. Según lo entendía, el vecindario tenía "el derecho de intervenir en el gobierno inmediato de la escuela local, donde tienen a sus hijos, y donde el maestro desempeña, como en el seno de la misma familia, una misión de confianza". ${ }^{40}$ En esta línea, proponía una inspección vecinal que debía ser

38 Congreso de la Nación, Cámara de Diputados, Sesión del 4 de julio de 1883.

39 Finalmente la ley permitió, en primer lugar, que se le garantizara a la mujer, en el marco de la educación primaria, los mismos programas y procedimientos escolares que fueron pensados para el varón. Una misma enseñanza que se diferenciaría en aquellos contenidos específicos que se le exigían a la mujer para el desempeño de su habilidad manual que le permitieran cumplir eficazmente con los que eran sus deberes usuales del hogar. Como se dejó expresa constancia, aquella escuela primaria a la que accedían las niñas tenía un sentido último: el de "educar a la hija del pueblo para que sea un día miembro útil de la sociedad". Esta cuestión ha sido trabajada en "Ciudadanas útiles para la patria. La educación de las 'hijas del pueblo' en Argentina (1884-1916)”, The Americas, 58:2, octubre, 2001, págs. 221-260.

40 Congreso de la Nación, Cámara de Diputados, Sesión del 4 de julio de 1883, pág. 482. 


\section{LUCÍA LIONETTI}

elegida por su pueblo. Esa comisión, formada por padres de familia, era la indicada para elegir, de una terna, al maestro que tenía la delicada función de educar a los niños de la comunidad. En síntesis, la propuesta de Leguizamón contemplaba una postura intermedia entre quienes defendían el derecho de la sociedad civil a diseñar y administrar las escuelas en las que se educaban "los hijos de la comunidad" y, las posturas centralistas que defendían el control de la educación por parte del Estado.

La intención de Leguizamón de acercar las posiciones no le quitó vehemencia y contundencia a su defensa de la educación laica, a la que consideraba el marco adecuado para el proyecto modernizador del país:

"Si la Constitución argentina es tolerante, la escuela tiene necesariamente que ser tolerante. Si la Constitución ha proclamado la libertad más absoluta de conciencia para los ciudadanos, la escuela no puede venir a alterar los principios de la Constitución borrándolos en la práctica y a hacer obligatoria la enseñanza de una religión determinada en esa escuela a que concurren los hijos de todos los habitantes y a que tienen derecho de concurrir, porque contribuyen con su peculio a sufragar la existencia de la escuela. [...] Las puertas de la República les quedarán cerradas. Ningún inmigrante va a un país en donde, por primera condición, la ley le impone para sus hijos una religión determinada. [...] El maestro que es civil, y lo será casi siempre, puesto que no exige, para ser maestro condiciones de comunión determinada, viene, por la ley, a ser obligado a enseñar una religión que, tal vez, no es la suya. [...] No es entonces, la escuela sin Dios lo que quiere el partido liberal en la Cámara. Los que piensan como yo, los que me hacen el honor de acompañarme en la cuestión que nos ocupan, dejan a Dios donde se encuentra; donde debe estar: en todas partes, según la verdadera noción de su omnipresencia.

Hacen más aún: dejan en completa libertad a todos los ciudadanos para que adoren a Dios como lo entiendan en el templo y fuera de él, en la ermita y fuera de ella, en el valle, en el monte, en público y en privado, sin imágenes ni símbolos, con tal que lo hagan en espíritu y en verdad, es decir comprendiéndolo y amándolo sinceramente". ${ }^{41}$

El argumento fue retomado por el legislador Lagos García. Explicó que no podía considerarse ateo a un Estado que no sostuviera determinada religión, sino que - en todo caso- la que no debía ser atea era la sociedad. El Estado, en tanto representante de la sociedad para fines determinados, tenía una misión diferente a la de la Iglesia: hacer reinar la justicia, hacer respetar los derechos, procurar que los hombres vivieran lo más felices que fuera posible. De manera provocadora llegó a afirmar:

41 Idem, págs. 483 a 484. 
“[...] no es cierto que la escuela que propone el proyecto que hemos presentado en sustitución de la Comisión, sea una escuela atea. No es atea la escuela en que se enseña la moral que reposa sobre las ideas de la existencia de Dios, de la inmortalidad del alma, de la Providencia y de la justicia divina. [...] La escuela que propone el contraproyecto presentado, es cuando más una escuela neutra, una escuela no sectaria. [...] Pero voy a demostrar algo que tal vez sorprenda a la Cámara, y que sin embargo, es la verdad, (...) la única escuela atea, la única escuela sin Dios que se establece, según esas doctrinas, es la que propone el proyecto de la Comisión.

El proyecto de la Comisión propone que se de la enseñanza por el institutor del dogma católico, a todos los niños cuyos padres pertenezcan a la comunión católica, quedando excluidos de la enseñanza de la religión a todos aquellos cuyos padres pertenezcan a las comuniones disidentes.

$\mathrm{Y}$ entonces yo digo que el proyecto de la Comisión que no permite siquiera entren allí, a enseñar religión, sacerdotes de cultos disidentes, es el que se crea la escuela atea para un número muy considerable de los niños de esta Capital y de los territorios nacionales $[\ldots] "{ }^{42}$

También estuvo presente para apoyar el proyecto del diputado Leguizamón el ministro Eduardo Wilde. En su disertación expresó que el ministro de Culto, Justicia e Instrucción Pública de una nación como la República Argentina no era el responsable de propagar la fe, ni de ser su apóstol, no debía enseñar una religión, ni proteger un culto en detrimento de otros. La historia había demostrado que el Estado tenía fines particulares como el de unir a los hombres entre sí, por su lado, la religión tenía la función de unir a los hombres con Dios, en una palabra: mientras el Estado se dirige a las colectividades, la Iglesia se dirige a los individuos,

"Por consiguiente, la religión que une íntimamente el individuo al Ser Supremo, no da lugar a responsabilidades, ni establece relaciones ni vinculaciones colectivas ante él, aun cuando las establezca entre los miembros de un mismo credo, para los fines terrenales que la Iglesia procura.

El Estado, por el contrario, dirige la vida de las asociaciones, responsabiliza a los grupos y lo hace todo con la acción en conjunto. De aquí resulta que, siendo diferentes los fines de la Iglesia y los fines del Estado, hay independencia recíproca. El Estado une a los hombres, ¿para qué? Para que los hombres se ayuden en la lucha por la vida, para que hagan posible el trabajo y, por lo tanto, el sostenimiento de los grupos y de los individuos que los forman. [...] Un Estado, en la concepción del derecho moderno, puede confesar la existencia en la mayoría de los que lo componen en una religión; es decir, afirmar en sus leyes que la mayoría del pueblo tiene tal o cual religión [...]. Pero eso no significará que el Estado, entidad colectiva, tenga lo que solo pertenece al individuo, una creencia, una religión. La religión es una concepción enteramente individual [...] Nadie se puede asociar para tener una religión [...].43

42 Ibídem, Sesión del 6 de julio de 1883, pág. 497.

43 Ibídem, Sesión del 13 de julio de 1883, pág. 557. 


\section{LUCÍA LIONETTI}

Con su alocución, llegó a plantear una cuestión cardinal en el debate: la relación entre el Estado y la Iglesia y la cuestión de la ley de educación:

"En la época moderna se presenta con toda claridad la diferencia que hay entre el Estado y la Iglesia; se ha llegado a ella y poco a poco, por la transformación de las ideas, por las conquistas especiales de la Iglesia sobre las creencias y del Estado sobre los intereses temporales, y nos encontramos en frente del concepto verdadero del gobierno político, del principio moderno, que es el Estado interconfesional. ¿Por qué? Porque los hombres siendo iguales en deberes ante el Estado, tienen que ser iguales en derechos; y uno de los derechos es la libertad de conciencia, derecho proclamado por la conciencia política, y reconocido a la par de todo otro derecho. [...] La religión, señor Presidente, es un refugio y un consuelo; el Estado es un protector de los derechos del hombre. Si se unen los dos poderes, este inmenso poder de la religión y este poder formidable del Estado en una sola persona, habrán desaparecido los derechos de los ciudadanos una vez que esa persona pudiera ser déspota, cruel o sanguinaria.

La Iglesia puede ser un refugio contra la injusticia del Estado, como dicen los pensadores, y el Estado es a su vez un protector contra la intolerancia de la Iglesia. [...] el verdadero principio moderno, proclamado en estas grandes palabras de Cavour, es: 'La Iglesia libre en el Estado libre'. [...] La Iglesia domina las creencias; el Estado domina las funciones políticas. [...] El temor por parte de los que han sido designados con el nombre de clericales, no se si con razón o sin ella, no es de lo que va a ocurrir en las escuelas, si esa enseñanza no se decreta; sino del significado que tendrá la declaración de las Cámaras de la Nación y del Poder Ejecutivo en un momento de conflicto para los intereses que los clericales sostienen en el mundo entero. Y precisamente, por contar planes tan funestos para el país, se empeña el Poder Ejecutivo en sostener que no se consigne en la ley la enseñanza religiosa; por no mirar atrás, como se ha dicho; por no dar, en una declaración oficial y en una sanción del Congreso, una prueba de atraso; por no decir, en fin: Con la ley de educación y de una manera indirecta, cierro las puertas a la corriente de inmigrantes de cuya afluencia necesita para el engrandecimiento de la Nación". ${ }^{4}$

El largo y sostenido debate, recuperado sólo en sus aspectos centrales, culminó con el rechazo del proyecto de la comisión y la aprobación del que presentara Leguizamón. La votación fue concluyente: cuarenta y tres votos contra diez. ${ }^{45}$ En definitiva, aquella controversia giró sobre dos tesis centrales: la de los católicos que defendieron el derecho de los padres a elegir el tipo de educación que desearan para sus hijos, proclamando el predominio de las familias católicas en el país, y la de los que consideraron la educación como una cuestión de Estado que debía priorizar la formación del ciu-

44 Idem, págs. 559 a 560.

45 Como un detalle anecdótico se puede comentar que los estudiantes de medicina, y luego los estudiantes de todas las facultades, organizaron una gran manifestación el 21 de julio de 1883 en la Plaza San Martín para agradecer a los diputados Onésimo Leguizamón, Emilio Civit, Delfín Gallo y Luis García, al ministro Eduardo Wilde y a la prensa liberal argentina. Ver, La Nación, 23 de julio de 1883. 
dadano. ${ }^{46}$ Era una querella en la que el pensamiento católico, antiindividualista y, en principio, respetuoso del orden social establecido se oponía a la educación liberal, centrada en el individuo y la confianza en el cambio, un antagonismo que durante el siglo XIX se expresó como un conflicto entre la tradición que encarnaba la Iglesia católica y la modernidad que se empeñaba en construir el Estado. Para los católicos, el conocimiento se sustentaba en los dogmas de la verdad revelada y la defensa de la familia frente al individuo como núcleo de la vida social. Por su parte, los liberales recuperaron la matriz ilustrada y sostuvieron que la primacía de los valores religiosos obstaculizaba la estructuración de una comunidad nacional, mucho más amplia que la sociedad religiosa, por definición excluyente. ${ }^{47}$

En la Argentina, la Iglesia era una institución relativamente reciente que comenzó a conformarse paralelamente al Estado en la década de $1870,{ }^{48}$ ambos procesos no fueron independientes y su carácter conflictivo derivó muchas veces de la necesidad de definir sus respectivos campos de acción ${ }^{49}$. Ese Estado nacional que propició y necesitó "nacionalizar" el clero encontró más acuerdos que debates con la Iglesia católica. La controversia, por tanto, se instaló a partir de la batalla librada entre ambas instituciones por controlar los espacios de socialización y de difusión de un principio organizador para la comunidad. En aquel contexto en el cual el Estado daba sus pasos firmes hacia su consolidación, los sectores católicos, "en retirada" 50 ,

46 Sobre esta cuestión se puede consultar el trabajo de Auza, N.T.: Católicos y liberales en la generación del 80, Buenos Aires, 1975. Un análisis más general aportó también este autor en: "The Catholic Church in Latin America, 1830-1930", The Cambridge History of Latin America, Cambridge, 1986.

47 Esta cuestión también se planteó de modo similar en toda Latinoamérica, para el caso mexicano se puede consultar: Loaeza, Soledad: "La Iglesia y la educación en México. Una historia en episodios", en Gonzalbo Aizpuru, Pilar: Historia de la educación y enseñanza de la historia, t. I de Historia y Nación, El Colegio de México, México, 1998.

48 Santamaría, Daniel: "Estado, Iglesia e inmigración en la Argentina moderna", Estudios Migratorios Latinoamericanos, 14 de abril 1990.

49 Sobre la importancia institucional que cobra la Iglesia católica en la Argentina, a partir de la década del '30, se puede consultar: Bianchi, Susana: "La conformación de la Iglesia Católica como actor político-social: el episcopado argentino (1930-1960)", en Bianchi Susana y Spinelli, María E.: Actores, ideas y proyectos políticos en la Argentina Contemporánea, IEHS, Tandil, 1997. En un interesante estudio sobre el mundo de los laicos, en particular las organizaciones de elite, la misma autora define a la Iglesia católica como un vasto sistema de circulación, centralizado y jerarquizado, pero también "capilarizado" al extremo, en Bianchi, Susana, "La conformación de la Iglesia Católica como actor político-social. Los laicos en la institución eclesiástica: las organizaciones de elite (1930-1950), Anuario IEHS, 17, Tandil, 2002, pág.143.

50 Halperin Donghi, Tulio: El Espejo de la historia. Problemas argentinos y perspectivas latinoamericanas, Sudamericana, Buenos Aires, 1987. 


\section{LUCÍA LIONETTI}

no encontraron las condiciones propicias para ser escuchados y neutralizar el discurso liberal en el marco de la pax roquista y de la promesa de que el programa modernizador obtendría éxito.

Se impuso la enseñanza libre en las escuelas primarias nacionales, y se dejó librado a las autoridades provinciales que decidieran sobre la posibilidad de que se dictara la enseñanza religiosa optativa los días sábados para aquellas familias que estimaran conveniente que sus hijos la recibieran. De todos modos, aquella controversia continuó y apareció con cierta recurrencia, alcanzando puntos de inflexión en momentos en que la educación pública era cuestionada por su supuesta ineficacia. En ese contexto, el reposicionamiento y la mayor ingerencia de los sectores católicos se hicieron presentes acusando a la escuela pública y sus maestros de formar a los niños sin la idea de Dios. El año 1906 fue paradigmático, en ese sentido, al evidenciar el avance de algunos gobiernos provinciales que, valiéndose del principio de jurisdicción sobre los establecimientos que dependían de su administración, decidieron imponer la enseñanza religiosa. Esa situación llevó a que el ministro Piñero ratificara, desde la nación, la libertad de enseñanza. Esa nueva disputa se trasladó al ámbito de la comunidad que tomó partido por uno u otro bando, tal como sucedió en la provincia de Córdoba:

"Un núcleo de personas caracterizadas se ocupa en hacer firmar un telegrama al ministro Piñero, felicitándolo juntamente con el presidente de la república, por el decreto de libertad de enseñanza". ${ }^{51}$

La directora de la escuela provincial de niñas pasó a una nota a la comisión vecinal escolar, informando de las torpes burlas provocadas por fanáticos enemigos de la enseñanza laica.

Las personas sensatas critican severamente los procederes del elemento ultramontano, instigador de estas burdas persecuciones". ${ }^{22}$

51 La Nación, 7 de abril de 1906, pág. 6.

52 Ibídem, 10 de abril de 1906, pág. 6. La toma de posicionamiento cuando se instalaba nuevamente el debate era inevitable. Así por ejemplo en la ciudad de Rosario, provincia de Santa Fe, donde, se gestó: “[...] un movimiento de opinión contra la nueva ley escolar sancionada por la cámara de diputados de la provincia, según la cual se establece la enseñanza religiosa obligatoria en las escuelas fiscales, debiendo estar a cargo de miembros del clero católico.

Esta ley, tan inoportunamente dictada, por cuanto ha venido a raíz de la afrenta al sentimiento liberal del país, por la cuestión de la entrada de la bandera nacional en los templos, ha repercutido desagradablemente entre los liberales, que se disponen a combatirla, organizando manifestaciones públicas contra el gobierno que la prestigia y contra los legisladores que la sancionaron”. Ibídem, 27 de junio de 1906, pág. 6. En cuanto al incidente mencionado por el cronista, se refiere a que durante la ceremonia del Te Deum en ocasión de celebrarse el festejo patrio del 25 de Mayo, el obispo de la ciudad prohibió el ingreso de la bandera nacional. 
La literatura fue un campo en el que incursionaron hombres del pensamiento católico para arremeter contra la enseñanza oficial y, particularmente, contra la figura de sus educadores. Ése fue el caso de Manuel Gálvez que, desde su obra más reconocida La maestra normal, cuestionó a los que tenían la misión de formar al ser nacional. A través de la ficción, el autor presentó a su protagonista, una maestra normal del interior del país, como el arquetipo de una educadora que no pudo encauzar su vida, lo que planteaba serias dudas sobre sus condiciones morales a la hora de formar a sus alumnos. ${ }^{53}$ Raselda reconocía arrepentida que había caído víctima de la seducción de un inescrupuloso director de escuela que la había dejado embarazada, y comete el hecho aberrante de interrumpir su embarazo. Había perdido su honra porque "nunca le hablaron de Dios, y algunos profesores le enseñaron hasta despreciar la religión. Ahora creía que esa enseñanza de la escuela, en vez de darle fuerzas para vencer los instintos, la había predispuesto para el mal, al quitarle las eficaces defensas que tiene la religión contra el pecado". ${ }^{54}$ Era una novela cargada de sentido dramático a partir de la cual uno de los mayores exponentes del nacionalismo católico ${ }^{55}$ hizo responsable a la enseñanza pública de transmitir valores que conducían a la disgregación del cuerpo social. Su propuesta de construir la identidad nacional, sustentada en las raíces hispanas y la defensa del catolicismo, lo llevó a declarar a través de Don Nilamón, uno de los personajes más sim-

$53 \mathrm{Al}$ elegir como protagonista a la maestra, no sólo habrá que pensar en que, según la visión del autor, las mujeres serían las más propensas a "perderse" sin una adecuada formación religiosa, se podría especular, por otra parte, que la novela se dio en un contexto donde la mayoritaria presencia femenina dentro del cuerpo docente fue visualizada con preocupación por algunos miembros de la elite. Otra cuestión que se deberá tener en cuenta es que, efectivamente trascendían al público con cierta recurrencia algunos "cruces amorosos" entre docentes y aspirantes al magisterio de ambos sexos. Por ejemplo, en uno de esos episodios seguidos con atención por la prensa se comentó: "[...] la gravedad de los hechos acontecidos en la Escuela Normal de Córdoba que culminaron con una tragedia romántica, impresionando la imaginación de las gentes porque existieron atracciones fatales entre los protagonistas y porque era personal del magisterio [...]”. La Nación, 22 de junio de 1906.

54 Gálvez, Manuel: La maestra normal. Obras escogidas, Ediciones Aguilar, Madrid, 1941, págs. 342-343. Esta obra ha sido analizada en su intencionalidad política desde la literatura por Golduchluk, Graciela: "La maestra normal de Manuel Gálvez. Un antinormalismo pedagógico", Estudios e investigaciones. Literatura argentina y nacionalismo, 24, 1995. Otro aporte desde el campo historiográfico se encuentra en Lionetti, Lucía: "Un campo de tensión por encauzar la 'moral'. Disputa, resistencia y convivencia entre la sociedad y los educadores (1900-1920)", en Gonzalbo Aizpuru, Pilar (Coord.): Familia y educación en Iberoamérica, El Colegio de México, México, 1999.

55 Sobre las aristas del pensamiento de los intelectuales de la derecha en la Argentina dentro de los que figura el citado Gálvez, ver Echeverría, Olga: Una inteligencia disciplinada y disciplinante. Los intelectuales autoritarios de derecha, su concepción estética, ideológica, política y social en Argentina primeros años del siglo XX, Tesis Doctoral, UNCPBA, Tandil, diciembre 2002. 
páticos y amables de su obra, “ $¡ E l$ normalismo es la peor plaga que puede invadir a un pueblo joven!". ${ }^{56}$

Sin embargo, más allá de la virulencia de las palabras de estos actores que no hacían más que posicionarse en la arena política de la época defendiendo a la religión católica como el principio organizador del orden social, no se pueden desconocer los puntos de encuentro que existieron entre estas posiciones aparentemente opuestas. La disputa no puede convertirse en la cortina de humo que oculte en qué medida el proyecto educativo oficial recuperó y resignificó un conjunto de valores que tradicionalmente había transmitido el catolicismo. Se trata de tener presente que el cruce verbal, las denuncias y las acciones de los unos y otros son una de las aristas del enfrentamiento. Detrás de esos encendidos duelos verbales había acuerdos que eran menos evidentes a la luz pública.

\section{Formar en la Virtud Cívica}

El modelo de educación pública, entendido como un derecho social que garantizara a todos los niños la escolarización y a todo adulto de llegar a ser un ciudadano educado, ${ }^{57}$ promovió la socialización política para cimentar un nuevo orden social. Para alcanzar ese propósito se diseñó un conjunto de contenidos a través del cual se transmitió una serie de valores, pautas y normas de conductas consideradas indispensables para la formación del ciudadano y la moralización de las costumbres. Ese modelo de comportamiento cívico, producto de un contexto histórico ${ }^{58}$ no quedó ligado solamente a la constitución del ciudadano consciente de sus derechos políticos y a su capacitación para el ejercicio del sufragio. ${ }^{59}$ Tampoco quedó restringido a la elevación del carácter moral de los súbditos de la nación. ${ }^{60}$ La modernización proclamada para aquella sociedad exigió el desarrollo de conductas, hábitos, gestos, modos, actitudes que comprendían esas expectativas pero también la superaban.

56 Gálvez: La maestral..., pág. 245.

57 Marshall, T.H.: Cidadania, classe social e status, Zahar, Rio de Janeiro, 1967.

58 Véase Escalante Gonzalbo, F: Ciudadanos imaginarios, El Colegio de México, México, 1992.

59 Rosanvallon, Pierre: La rivoluzione dell'uguaglianza, Anabasi, Milán, 1994.

60 Sarmiento, D.F.: Educación Popular, Biblioteca Argentina, Librería de La Facultad, 1915. 
Para hacer posible esa socialización política se proyectó una educación de carácter integral que comprendía el dictado de varias materias: lectura y escritura; aritmética (las cuatro primeras reglas de los números enteros y el conocimiento del sistema métrico decimal y la ley nacional de moneda, pesas y medidas), geografía particular de la República y nociones de historia general; idioma nacional, moral y urbanidad; nociones de higiene; nociones de ciencias matemáticas, físicas y naturales; nociones de dibujo y música vocal; gimnástica y conocimiento de la Constitución Nacional. Para las niñas fue obligatorio además el conocimiento de labores de manos y nociones de economía doméstica; para los varones, el conocimiento de los ejercicios militares más sencillos; y, en las campañas, nociones de agricultura y ganadería. ${ }^{61} \mathrm{El}$ propósito que se perseguía era el de desarrollar las potencialidades intelectuales, físicas y morales del individuo, ${ }^{62} \mathrm{el}$ adecuado equilibrio en esa formación entregaría a la nación "hombres sanos, honestos, veraces, trabajadores, sin prejuicios, tolerantes, fuertes de cuerpo y de alma con todos los sentimientos que lo dignifican, fieles a la patria y con moralidad en sus costumbres". ${ }^{63}$

Un ciudadano, digno hijo de su patria ${ }^{64}$, debía mostrar un comportamiento conforme a las normas. La misión de la escuela era la formación necesaria para que el niño llegara a ser un hombre virtuoso, que cumpliera su deber como buen jefe de familia y buen trabajador de lo que se desprendía su condición de buen ciudadano. Los individuos que habitaran la república debían asumir conductas públicas y privadas que definían el perfil de ese modelo de ciudadanía. La honra, la honestidad, el cumplimiento de sus obligaciones familiares, el respeto a las leyes y las autoridades, el amor a

61 Ibídem, N. ${ }^{\circ}$ 63, 1884.

62 Los aspectos de esa formación han sido analizados en la tesis doctoral, Lionetti, Lucía: “La socialización política y la formación de los formadores en Argentina, 1870-1916”, presentada en la Universidad Autónoma de Madrid, junio 2001.

63 Pizzurno, Pablo: "La educación cívica y patriótica, 1908", El Educador Pablo Pizzurno. Recopilación de Trabajos, CNE, Buenos Aires, 1938, pág. 221. El autor de este texto, uno de los primeros maestros normales formados en la Escuela Normal de Paraná y destacada figura del pensamiento pedagógico argentino, cumplió varias funciones dentro del sistema educativo razón. Por esta razón, se puso en su memoria el nombre de Palacio Pizzurno al Ministerio de Educación de la Nación Argentina.

64 Sobre la cuestión de la construcción de la nacionalidad argentina a fines del siglo XIX el cruce entre las dos posturas dos posturas, aquella que pensaba la nación desde una concepción "esencialista" y excluyente y la que se inspiró en una matriz "contractualista" de herencia ilustrada con posturas liberales y cosmopolitas, ver: Bertoni, Lilia Ana: Patriotas, cosmopolitas y nacionalistas. La construcción de la nacionalidad argentina a fines del siglo XIX, Fondo de Cultura Económica, Buenos Aires, 2001. 


\section{LUCÍA LIONETTI}

la patria eran las aristas más evidentes toda vez que se explicitaba ese modelo proyectado. Esos preceptos había que difundirlos para que la comunidad erradicara los males y vicios que se denunciaban en aquella sociedad donde todo parecía trastocarse. Se proponía recuperar, frente a lo percibido como formas desbordadas de conductas y costumbres, aquellos comportamientos estimados como correctos. Principios, modales, gestos y valores debían llegar a todos los niños para que los aprehendieran en tanto eran hábitos que otorgaban respetabilidad. Todos, pobres y ricos, nativos e inmigrantes, tenían el derecho y el deber de superarse y elevarse moralmente controlando los impulsos y las actitudes desmedidas. Las palabras del secretario del Consejo Escolar de la Sección 7. a de Buenos Aires eran claras en ese sentido:

"La población de este distrito o sección, es en general, trabajadora, y como consecuencia lógica, la educación que los niños reciben en el hogar doméstico, no es la más recomendable.

Para que esta dificultad vaya desapareciendo poco a poco, he procurado insistir mucho cerca de los preceptores, a fin de que reclamen de sus alumnos posturas convenientes, modales dignos de personas cultas, aseo constante, lenguaje regular, etc., en una palabra, que corrijan todas aquellas cosas que acusan falta de respeto a la clase y a los encargados de educarles, acostumbrándoles a que demuestren en la calle la educación que reciben". ${ }^{65}$

El carácter de esa educación estimada como "recomendable" para civilizar las costumbres quedó claramente plasmado en el programa de Moral y Urbanidad. En el curso de los seis años de escolarización obligatoria se trataban los siguientes puntos:

En 1. ${ }^{\circ}$ grado: Moral: conversaciones, pequeños relatos, poesías y ejemplos morales, llamados a despertar el sentimiento del deber, enaltecer la virtud y condenar el vicio. Enseñanza práctica, observando las inclinaciones de niño, fomentando las buenas y corrigiendo las malas. Urbanidad: aseo en la persona, vestidos y habitación. Modo de conducirse en la casa y en la escuela. Buenos modales.

65 El Monitor de Educación Común, II, 67, 1884, pág. 432. Esta publicación del Consejo Nacional de Educación tenía como propósito difundir a los maestros y autoridades educativas, las medidas implementadas en esta materia, los informes de los inspectores nacionales, al tiempo que publicaba una serie de notas editoriales donde se trataban cuestiones pedagógicas. En adelante, $E l$ Monitor. 
En 2. ${ }^{\circ}$ grado: Moral: conversaciones, pequeños relatos, poesías y ejemplos morales, llamados a despertar el sentimiento del deber, enaltecer la virtud y condenar el vicio. Enseñanza práctica, observando las inclinaciones del niño, fomentando las buenas y corrigiendo las malas. Urbanidad: aseo en general. Decencia, elegancia y lujo. Modo de conducirse en los juegos, comidas y visitas y diversiones. Buenos modales.

En 3. ${ }^{\circ}$ grado: Deberes consigo mismo. El cuerpo: aseo, sobriedad, gimnasia. Perjuicios de la gula y embriaguez. El alma: veracidad, estudio y trabajo. Aversión a la ignorancia y la pereza. Modestia, paciencia, valor, dignidad personal. Deberes con los padres: obediencia, respeto, amor, gratitud. Auxilio en las enfermedades y en la ancianidad. Amor y protección entre los hermanos. Afabilidad con los sirvientes. Deberes con los maestros: asistencia y aplicación. Deberes con la Patria: grandeza y porvenir de la República. Deberes con la Patria: obediencia a las leyes, servicio en las armas, impuesto, voto. Urbanidad: reglas de urbanidad para con las autoridades, los parientes, los amigos, vecinos y criados.

En 4. ${ }^{\circ}$ grado: Deberes con los otros hombres: Justicia y caridad. Respeto a la vida, a la reputación, a la propiedad y a la libertad de los otros hombres. Fraternidad. Relaciones respecto de los bienes: Economía. Funestas consecuencias del juego y la ambición. Prodigalidad. Avaricia. Trabajo. Ahorro. Deberes para con Dios: Amor y respeto a Dios, como Creador y Providencia. El cumplimiento de los deberes que dicta la conciencia. Tolerancia con los sentimientos religiosos bajo las diversas formas que se manifiestan. La enseñanza se debería dar a través de lecturas, explicaciones, ejemplos que despertaran y robustecieran el sentimiento del deber y de la responsabilidad, absteniéndose de entrar en los dogmas y doctrinas religiosas, reduciendo el estudio a las nociones esenciales de moral comunes y necesarias a todos los hombres civilizados. Urbanidad: reglas generales de urbanidad.

En 5. ${ }^{\circ}$ grado: Moral: ideas fundamentales, el bien y el mal. El deber y el derecho. La libertad. La responsabilidad. Virtud y vicio. La ley moral y la ley escrita. Moral individual: deberes respecto del cuerpo. Conservación y desarrollo del organismo. El suicidio. Educación de las facultades. El trabajo. Moral doméstica: importancia y carácter de la familia. El matrimonio. Deberes entre los esposos, entre padres e hijos, entre hermanos. Deberes entre patrones y sirvientes.

En $6^{\circ}$ grado se revisaba los contenidos de Moral individual y doméstica (programa de $5{ }^{\circ}$ grado). Moral social: necesidad y beneficios de la 


\section{LUCÍA LIONETTI}

sociedad. Deberes de justicia. Respeto a la vida: legítima defensa, duelo. Respeto a la honra: injurias, calumnias. Respeto a la libertad. Promesas. Lealtad. Fiel cumplimiento. Deberes de caridad: su carácter. Moral política: la patria, el Gobierno, los ciudadanos. Autoridad pública. Deberes cívicos: obediencia a las leyes, servicio militar, impuestos, voto. Deberes de los gobernantes. Armonía del orden y de la libertad.

Su tratamiento debía orientarse a lo largo de "toda la vida de la escuela, el templo de la educación", ${ }^{66}$ fundado en una sana moral con la práctica de ejercicios que se orientaran sobre los mismos actos de los niños. El maestro, el "sacerdote de los tiempos modernos", ${ }^{67}$ debía ser el ejemplo y el modelo de conducta a imitar. La prédica del ejemplo era el consejo que se daba a los maestros para el dictado de la materia. Por eso, su enseñanza no debía ser una mera teoría que inculcara principios, sino el de "tratar de hacerlos cada día más morales y urbanos". Para ello, era preciso que cumpliera con rigurosidad su tarea docente, manteniendo en orden la casa y el ajuar de la escuela, favoreciendo el sentimiento de sociabilidad entre los alumnos, estimulando el amor a la verdad y la justicia ante sus estudiantes. La recta conducta del maestro tenía más sentido que todas las disertaciones sobre los deberes del hombre para con Dios, para con sus semejantes, para con sus padres. En definitiva, el niño debía aprender con los ejemplos cotidianos que la moral era la "ciencia del bien obrar" puesto que,

“[...] nos enseña a ser buenos con todas nuestras obligaciones. [...] Una obligación es algo que tenemos que hacer [...]. Las obligaciones que tenemos que llenar se llaman deberes. Obedecer a vuestros padres es un deber; no tomar lo ajeno, estudiar vuestras lecciones, venerar a Dios, ser gratos a vuestros maestros, asear vuestro cuerpo, servir a la Patria, etc. son deberes también". [...]. ${ }^{68}$

Al profundizar en los contenidos que se trataron en estos programas, se puede comprobar que el modelo de buen comportamiento que se proyectó desde la escuela laica recuperó los valores y las normas de las enseñan-

66 Pizzurno, Pablo: Consejo a los maestros, cómo se forma al ciudadano. Establecimiento Tipográfico El Comercio, Buenos Aires, 1888, pág. 2.

67 El Monitor, X, 191, 1890. En sus palabras el ministro de Instrucción Pública, Dr. Filemón Posse, en la Conferencia Pedagógica aconsejaba a los maestros que "imitaran a Jesús que llamaba a sí a todas las criaturas y les brindaba consejos con sus dulces y cariñosos afectos". Idem.

68 La Escuela Moderna. Serie elemental de Instrucción primara. Lecciones cortas sobre moral, Cabaut y Compañía Editores, Buenos Aires, 1915. 
zas católicas. Por lo tanto, no resulta extraño encontrase con comentarios como el siguiente:

\begin{abstract}
"Habiendo tratado hasta aquí de las materias que se refieren al mundo y al hombre debiera entrar ahora en otras que se refieren a Dios. Pero es tema este que no se puede tocar, y fue muy bien pensado el no hacerlo figurar en modo especial en los programas, porque Dios representa el Absoluto, y este es impenetrable a la mente humana. [...] Queriendo penetrar más allá, se limitaría la esencia Divina y se crearía un Dios humano. Se han de observar sin embargo ciertos destellos de la Divinidad en cuanto se refiere a la humanidad para que esta se encamine por la senda del bien. Pero la Moral no se ha de estudiar en los libros ni ha de hablar en una hora determinada para semejante enseñanza, pues de este modo no se obtendrían los resultados prácticos que se buscan. El maestro, a cada instante, tiene ocasión de insinuar en el corazón de los alumnos el sentimiento del bien, del deber, del amor, del respeto, de la caridad, de la fraternidad, del perdón, de la humildad, de la tolerancia y de la misericordia en oposición al odio, a la venganza, al orgullo, a la ostentación, a la soberbia, al egoísmo, etc., Cristo, este modelo perfecto de virtud, enseñaba principalmente por ocasión". ${ }^{9}$
\end{abstract}

José de San Martín, Manuel Belgrano, Mariano Moreno, Bernardino Rivadavia, los hombres que habían forjado la historia nacional en esa operación de "invención de la tradición", podían convivir perfectamente junto a la figura de Cristo como ejemplos de comportamiento virtuoso sobre el que se fundaba la ciudadanía republicana. Si bien se dejaba constancia de que en la enseñanza oficial no se podía enseñar ningún dogma religioso, los preceptos de la moral católica fueron válidos para el modelo de conducta republicana. Cuando se proclamó que el control de las pasiones, la moderación de los impulsos, la atemperación de las emociones y la regulación de la fuerza física llevarían a la moralización de la conducta y al imperio de la civilización, hubo una convivencia con aquellos hábitos de moralidad proclamados por la Iglesia católica. En el proyecto de construcción de la ciudadanía implementado a fines del siglo XIX en la Argentina se promovió la sumisión como virtud. El orden fue considerado requisito indispensable para el progreso y para ello se promovió el deber para con los padres, maestros, Gobierno y Dios. El vínculo de subordinación consolidado y consagrado por la religión fue válido para los dirigentes que proyectaron aquel plan de ingeniería cultural que se proponía construir a la nueva sociedad civil.

69 El Monitor, XXIII, 17, 1900. 


\title{
LUCÍA LIONETTI
}

\section{Algunas consideraciones finales}

Figuras como las de Pedro Goyena expresaron incansablemente en la arena pública su perturbación por el rumbo de la República. Como sostenía,

\begin{abstract}
"La vida de la República ha sido tumultuosa, [...] hemos pasado muchas veces por días aciagos; las pasiones han estallado estruendosas y fatalmente, la venganza ha inmolado millares de víctimas; el orgullo ha hinchado muchos corazones y oscurecido muchas inteligencias; hombres y pueblos se han extraviado en las sendas tortuosas de las falsas doctrinas, hasta llegar a una época de servil imitación de aquellos países donde se considera como halagüeño progreso, un positivismo mezquino y repugnante que pretende elevar a la categoría de principio la torpe sensualidad" ${ }^{70}$
\end{abstract}

Estas expresiones fueron el producto de las numerosas tensiones que se manifestaron entre católicos y liberales en estos años, sobre todo, cuando lo que se ponía en juego era la consolidación de un orden político fuerte de tono centralista ${ }^{71}$ y la construcción de una noción de nacionalidad. ${ }^{72}$ Pero lo cierto es que hubo una coincidencia de objetivos entre el Estado Nacional y una Iglesia que, en el caso de la Argentina, estaba en pleno proceso de construcción según el modelo jerárquico de Roma. En ese proceso de consolidación de uno y de construcción de otra, se generaron tensiones que estaban vinculadas a la definición de espacios de competencia.

En ese contexto, el tratamiento y la aprobación de leyes sobre temas que habían sido de competencia de la Iglesia Católica estaban vinculados, sobre todo, a la necesidad de un Estado que buscaba implementar las medidas necesarias para la centralización de una administración acorde a los nuevos tiempos de transformación económica y de social. Por su parte, los sectores católicos y la propia Iglesia utilizaron la disputa contra el impulso

70 Goyena, Pedro: “Introducción”, en Salvaire, Jorge María: Historia de Nuestra Señora de Luján. Su origen, su santuario, su Villa, sus milagros y su culto”, Buenos Aires, 1885, t. I, págs. LXXVI y LXXVII. Citado por Romero, Laura: Catolicismo y Nacionalidad. El culto de la Virgen de Luján según la obra del Padre Jorge Salvaire (1870-1900), Tesina de Licenciatura defendida en Tandil, UNCPBA, octubre de 2003. Como explica la autora, el culto de la Virgen de Luján se confunde con el de la historia de la Nación de modo que favorece el proyecto de construcción de la Iglesia Católica argentina a través del cual se identifica al catolicismo con la nacionalidad, intentando transformar a la religión en el principio organizador de la sociedad. Pero al mismo tiempo, las autoridades del Estado Nacional veían, por su parte, la coincidencia con sus objetivos de búsqueda de una tradición patria en la que podían reflejarse las masas de inmigrantes de las cuales no podían verse aún los efectos que causarían en la sociedad. Véase págs. 121-122.

71 Botana, Natalio y Gallo, Ezequiel: De la República posible a la verdadera (1880-1910), Ediciones Ariel, Buenos Aires, 1997, pág. 35.

72 Bertoni: Patriotas, cosmopolitas... 
secularizador de las autoridades civiles para cohesionarse internamente y posicionarse en el escenario político de la época.

El campo educativo fue el ámbito recurrente sobre el que volvieron unos y otros cada vez que buscaron fortalecer sus posiciones ideológicas y políticas. De este modo, se trasladó al escenario argentino el clásico conflicto europeo entre católicos y liberales. Sin embargo, esa disputa en la Argentina tuvo sus particularidades; los católicos liberales laicos tuvieron una activa participación en la definición del proyecto educativo estatal. Una clara evidencia se encuentra precisamente en el diseño del espacio curricular de la asignatura Moral y Urbanidad en la que se transmitieron las formas de comportamientos virtuosos que tradicionalmente había transmitido el catolicismo, más allá de la proclamada laicidad. Si la Iglesia no podía llegar a todas las latitudes del país, si no se contaba con el número de sacerdotes suficientes, si efectivamente la escuela se había convertido en la institución con mayor alcance en la formación, bien se podían valer de ella para llegar a todos los niños del país, hijos de familias católicas, protestantes o "ateas" bajo el paraguas de la escuela pública. A su vez, es factible hallar otra derivación de esta cuestión. Se puede pensar que, más que existir una confrontación entre los valores defendidos por el Estado liberal y la Iglesia católica, fue posible que hubiera una convivencia. En todo caso los valores, pautas y normas de comportamiento, que se pretendían transmitir en la escuela, revelaron la funcionalidad de los principios católicos para los dirigentes liberales que buscaron moralizar las costumbres de los habitantes del país. Bajo la fórmula de transmitir los contenidos que definían lo que se entendía por moral y sin llegar a referirse a un dogma, la enseñanza laica utilizó un dispositivo normativo que tuvo más puntos de contacto que diferencias con lo que se transmitía en la enseñanza religiosa. Una convivencia que no sólo habrá que buscarla en términos institucionales, en la relación entre el Estado y la Iglesia, sino en lo que se designaba como un comportamiento virtuoso. Como explican Di Stefano y Zanatta, en principio, la modernización que determinaba la vida social y que introducía en ella ideas y estilos de vida heterogéneos diferenciaba las actividades y las expectativas de los individuos y cambiaba las escalas de valores y las concepciones de la autoridad y de la jerarquía social. ${ }^{73}$ Sin embargo, en el caso argentino, gran parte de la elite no cuestionaba el carácter cristiano de la

73 Véase Di Stefano, R.; Zanatta, L.: Historia de la Iglesia Argentina. Desde la Conquista hasta fines del siglo XX, Grijalbo-Mondadori, Buenos Aires, 2000, pág. 311. 
civilización que debía implantarse en las tierras sustraídas de la "barbarie" y apreciaba la función "civilizadora" del clero siempre que no contradijera su "proyecto de nación"74. Lo que ha sido presentado como una competencia entre la autoridad temporal y la espiritual, el ciudadano y el fiel, que habría significado el avance en el mundo occidental de las ideas y conductas de la sociedad burguesa, vuelve a sugerir, como otra opción explicativa en el caso argentino, la posibilidad de estimar la recuperación de los valores tradicionales en pleno contexto de la secularización y de advenimiento del discurso modernizador.

Recibido el 17 de febrero de 2004 Aceptado el 20 de octubre de 2004

74 Ibídem, pág. 332. 